\title{
Building Virtual Bridges: How Rural Micro-Enterprises Develop Social Capital in Online and Face-to-Face Settings
}

\author{
Leanne Townsend, Claire Wallace,* Alison Smart and \\ Timothy Norman
}

\begin{abstract}
In rural UK, businesses are often isolated and have much to gain from healthy networks, yet studies show that many rural business owners fail to network effectively. Information communications technologies offer new ways to network that might benefit rural businesses by expanding their reach. This study looked at online and face-to-face networking behaviour among rural micro-enterprises in Scotland in relation to the development of bonding and bridging social capital. Given the challenges of remoteness faced by many rural businesses, online networking is particularly useful in developing bridging capital, but is an unsuitable context for building the trust needed to gain tangible benefits. The article therefore highlights the importance of face-to-face interactions in developing trust and bonding social capital. Rural business owners face distinctive challenges with respect to online communications, which are explored in this article.
\end{abstract}

\section{Introduction}

T $\mathrm{n}$ this article we focus on the networking behaviour of rural business owners as a key route to the development of social capital. In rural UK businesses face distinctive challenges (Townsend et al. 2013). Geographical remoteness isolates businesses from one another, suppliers and clients. Networking is arguably crucial for small businesses in order to overcome problems of remoteness and build social capital, yet studies show that rural business owners do not always network effectively (Burgess 2008). Social capital has gained popularity as a potential means of enhancing the social and economic sustainability of rural regions; in the EU, for example, through the LEADER programme (Shucksmith 2000), with such approaches highlighting the role of networks. The widespread need for improving social capital in 
rural development has often been unquestioned, with little research revealing how it can be facilitated in rural communities, particularly at the informal level, that is, with no formal input and support from development agencies (Sutherland and Burton 20II); something that is increasingly pertinent in a time of austerity measures. Social capital is a useful yet contested construct; one that requires ongoing attention given its popularity among policymakers and development agencies (Sutherland and Burton 20II).

Although the role of social capital for small rural businesses has received some attention in the literature, this has failed to consider the role of online communications. Information communications technologies (ICT) offer new ways for rural businesses to network within and outside communities, yet little is known about what kinds of networks are enhanced and how ICT is used by rural business owners. Does it help to overcome the disadvantages of remoteness and isolation, and the costs of distance faced by rural businesses? Does ICT serve to reinforce bonding or bridging social capital, or both? The article addresses our understanding of how rural businesses use social capital in online interactions, something that has not been well researched so far.

We begin by considering networking behaviour as a route to social capital in the context of rural businesses, giving special attention to online networking. We then outline the methodology and present a qualitative analysis of the interview data, focusing on how bridging and bonding relates to online and offline networking among rural business owners. We conclude with reflections and recommendations on the role of social capital as a framework in rural economic development. The findings offer a useful context for the exploration of social capital and shed muchneeded light on its peculiarities in rural business contexts.

\section{Social capital and rural business networking}

Social capital is understood as the value obtained from participating in social networks (Putnam I993, 2000; Halpern 2005) particularly in terms of supporting economic development (Lee et al. 2005). For Putnam, social capital is the glue that binds people together. It builds the trust that forms the basis of flourishing business relationships, as well as reinforcing social norms. Knack and Keefer (I997) develop this further, arguing that trust and the reinforcement of social norms leads to contract compliance, hence social capital enables business to flourish. For example, a business owner is less likely to violate an agreement if it means being thrown out of a business association and others refusing to deal with them, as this leads to reputational damage more generally. Further, Putnam describes social capital as a collective good benefiting the wider community and stresses notions such as altruism and collective action (Anderson and Jack 2002; Halpern 2005). In contrast, Bourdieu (I984) sees social capital as a personal asset used by those with higher status to maintain their positions and exclude others, emphasising power relations within networks. Thus, social capital can have negative consequences for those with lower positions in the social hierarchy.

The literature identifies two distinct forms of social capital: bridging and bonding (Putnam 2000). Bonding social capital refers to close relationships in small groups

(c) 2014 The Authors. Sociologia Ruralis published by John Wiley \& Sons Ltd on behalf of European Society for Rural Sociology.

Sociologia Ruralis, Vol 56, Number 1, January 2016 
which contain trust but stress ties of obligation and which can lead to the exclusion of wider relationships (Portes I998). Bridging social capital, implying access to wider groups, can span structural holes in networks and is often seen as more advantageous than bonding capital in accessing opportunities, for example, for employment and social mobility (Coleman I988; Lin 200I). However, the weaker connections associated with bridging also imply less obligation and trust. Similarly, networks are conceived in terms of strong and weak ties (Granovetter I973; Shaw I997; Chell and Baines 2000). Strong ties, associated with bonding social capital, refer to close and trusting relationships. Weak ties, similarly to bridging social capital, refer to less well-established relationships arising from wider networks and containing less trust. Bridging social capital often implies an active involvement in civil society organisations (Pichler and Wallace 2007), in which individuals of higher social class have more bridging associations and those in lower social classes having more bonding associations (Pichler and Wallace 2009). The literature offers little explanation of the extent to which bridging and bonding are distinctive. However, it is suggested that bonding and bridging social capital may not be mutually exclusive but may instead be two aspects of the same process (Anderson and Jack 2002; Phillipson et al. 2006).

We define networks as clusters of social relations that facilitate the exchange of information and resources, similar to the understanding posited by Lee et al. $(2005)$ - networks as webs of social relationships articulating the flow of information, resources and identities located at a level below that of Castells' (I996) global society. We highlight the social element, in agreement with Petrou et al. (2007): 'Business networks ... are social networks illustrating the effects of personal relationships and the sharing of common concerns, ideas and opinions' (p. 427). We highlight the understanding of network theorists that benefits derived from networks are not derived merely from direct ties but also from resources that may be mobilised through indirect ties across the broader network structure (Adler and Kwon 2002, p. 98). These are dependent upon the extent of structural holes (links to individuals and groups not otherwise connected) in the network, or the extent to which a person's contacts are connected with one another (Coleman I988). More open network structures can lead to the violations of norms, which erode trust. On the other hand, Burt (I992) argues that sparse networks with structural holes act as a source of social capital, rather than eroding it. It is acknowledged that networks reflect power relations in professional and place-based communities (Bourdieu I984). The outcomes of network membership then will depend upon the structure of the ties and the distribution of power throughout the group.

The business literature has stressed the importance of social capital developed through networking (Bryson et al. I993; Pittaway et al. 2004; Atterton 2007), for example, as a source of innovation (Roper 1997), a facilitator of sustainability in small firms and a means of accessing skills and services (Bryson et al. I993). Networks of local businesses with varying skills can develop new opportunities that generate mutual competitive advantage (Ashcroft et al. I995) and develop trust that reinforces contract compliance (Knack and Keefer I997), illustrating the tangible benefits of social capital.

(C) 2014 The Authors. Sociologia Ruralis published by John Wiley \& Sons Ltd on behalf of European Society for Rural Sociology.

Sociologia Ruralis, Vol 56, Number 1, January 2016 
The rural context. Social capital is of particular importance for rural businesses (Chell and Baines 2000; Lechner and Dowling 2003). Geographical remoteness can isolate rural businesses from one another and from potential clients (Townsend et al. 20I3). Networking builds social capital which can be used to address the problems of rural isolation, for example, in connecting disparate businesses, allowing them to expand their business reach (Moyes et al. 20I2), provide integrated services (Petrou et al. 2007) and overcome logistics costs associated with remote locations. Networking is appropriate in rural regions because rural business owners typically demonstrate high levels of commitment to their local community (Bosworth 2009) and their social and professional ties often overlap (Monsted I995).

It has, however, been argued that rural businesses do not always network as fully as they could (Curran et al. 2000; Dinis 2006; Burgess 2008; Moyes et al. 2012), therefore failing to develop adequate levels of social capital. Formal networking initiatives often suffer from low levels of participation (Phillipson et al. 2006). Curran et al. (2000) point out that rural businesses are often based in sparsely populated areas that contain fewer businesses to network with (Dinis 2006). Ironically, while rural businesses might be expected to rely on networking to overcome problems of rurality, rurality itself makes networking more challenging.

Granovetter (I973) argues that weak ties allow people to reach broader groups that are not available to them through (typically closer) strong ties. Reaching beyond strong ties to lesser-known networks may offer new opportunities and enhance bridging social capital (Portes I998). Yet the literature suggests that for rural businesses, networks are typically characterised by strong ties that stress bonding social capital (Gilbert et al. 2008; Ring et al. 2010). Such networks can become conservative and fail to make use of new opportunities (Chell and Baines 2000; Atterton 2007). Similarly Atterton (2007) found that rural businesses' networking behaviour might suffer from 'over-embeddedness' (p. 240), emphasising strong ties held within the immediate locale. Rural business communities therefore may benefit most from the fostering of bridging social capital which opens up opportunities outside the immediate environment, which is particularly valuable considering their often isolated geographical situation.

Networking online. ICT potentially offers news ways to network and subsequently build social capital, particularly for small businesses (Buhalis and Main I998; Deakins et al. 2004; Galloway and Mochrie 2005; Hansson et al. 2007) as it provides 'an enhanced feeling of access to, and communication with, the world beyond their local settings' (Hansson et al. 2007, p. 48) and grants access to wider resources and suppliers (Kaplan and Sawheny 2000). Online communications can take the form of e-mail, websites and links to electronic markets such as eBay, but also include online social networking sites such as Twitter, Facebook and LinkedIn that are increasingly used to promote business activities.

ICTs have enabled the emergence of new dimensions of social capital (Wallace 20I2). Studies suggest that networks may become larger and more loosely tied as a result of ICT use (Wellman, Quan Haase and Witte 200I), and that relationships may be increasingly dis-embedded from the locality (Giddens I99I). The easier flow of information and formation of new communities imply new kinds of economic and 
social relationships across distances and within communities (Castells 20II). Resnick (2005, p. 400) describes 'sociotechnical capital' that may be enhanced through the use of ICTs but suggests that although ICTs can support personal relationships and bridge time and distance, they are not as effective as face-to-face interactions - a position later echoed by Galloway and Mochrie (2005). This view suggests that despite their usefulness, ICTs and their role in developing social capital should be understood differently from face-to-face networking. Yet little has been written about online networking and its role in social capital development for businesses. The relationship of online networking with social capital is considered largely in terms of broader groups, or in terms of civic or political participation (see Resnick 2005; Valenzuela et al. 2009; Ellison et al. 20II; Gil de Zuniga et al. 2012). Nothing has yet been said about how social capital might develop differently for businesses in online and face-to-face contexts.

In Castells network society, technology allows the development of new, potentially global networks, which are less constrained by time and space: 'TT]he new communications system radically transforms space and time, the fundamental dimensions of human life. Localities become disembodied from their cultural, historical, geographical meaning, and reintegrated into functional networks' (Castells i996, p. 357). The network society can result in new virtual geographies forming new networks of practice and exchange, no longer dependent upon physical space (Burnett and Marshall 2003). This 'shrinking of the world' (Agnew 200I, p. I33) has been referred to as time-space compression - the dissolution of more traditional temporal and geographical spatialities which impact on the flow of people, goods, capital and culture (Burnett and Marshall 2003). These notions existed before Castells' work: for example, in ig62 McLuhan suggested that technology would bring people and economies together in a 'global village' (McLuhan I962, p. 48). Yet globalisation narratives often point to globalisation processes as being mostly relevant to urban geographies and as applying less to rural areas, emphasising the benefits for well-connected regions with access to good, fast technology. This illustrates another area of urban bias in the literature (Agnew 200I).

We argue that globalisation is relevant to rural economies, for example, where these represent meaningful linkages with urban centres or other, remote rural regions. These linkages are moving the economic identity of rural regions away from a sole focus on agriculture and land-based economies to encompass, for example, tourism, food and drink and recreation industries (all of which are represented in our sample) (Gibson 2002). This view more positively speaks to the potential of technology in empowering rural businesspeople which might previously have been geographically disconnected from professional networks and peers. It is suggested that online activity can increase participation in rural community life (Stern 2008) and reduce the barrier of distance for rural communities (Skerratt and Warren 2003), and that problems such as limited local markets can be tackled collectively through online business forums (Galloway et al. 2004) which facilitate collaboration through the exchange of resources, information and ideas (Deakins et al. 2004). Yet despite these insights, little is known about how rural regions can develop social capital through online networking (Stern and Adams 2010) and how this might differ between bonding and bridging social capital. Online networking is powerful in bridging 
individuals and networks (Ellison et al. 20II; Hampton et al. 20II) - perhaps particularly so for rural businesses that may be isolated and have low bridging social capital. Online networking may thus have a significant potential to enhance rural businesses.

Unfortunately, the technological landscape in rural areas is not easily comparable to the urban context. Historically, many rural areas have shown lower levels of adoption of digital technologies in comparison with their urban counterparts (Smallbone et al. 2002; Hansson et al. 2007; Warren 2007) and have lower levels of digital competence than urban areas (Galloway and Mochrie 2005). This forms part of a phenomenon known as the digital divide - the division in society in terms of how different groups access and adopt digital technologies (Warren 2007). The digital divide has been associated with demographic characteristics of rurality such as low income, low educational levels and ageing populations (Leatherman 2000) although this may be changing due to middle-class in-migration (Bosworth and Willett 20II; McGranahan et al. 20II). A further issue impacting on the digital divide is that historically, the availability of Internet access in rural areas has been well below what has been made available in urban areas in terms of upload and download speeds (Townsend et al. 20I3). Since the emergence of Web $2.0^{\mathrm{I}}$ in the late I990s, businesses have increasingly depended upon reliable access speeds in order to sustain, grow and compete (Townsend et al. 2013), and, in particular, this advancement of web applications has entailed better opportunities for individuals and organisations to communicate and collaborate remotely. Therefore, poor access speeds disadvantage businesses based in rural areas. Despite UK government's efforts to improve broadband speeds in rural areas (Department for Culture, Media and Sport 20II), a recent Ofcom report shows that of the 5 per cent of UK residents who cannot access broadband of at least $2 \mathrm{Mbps}$, 60 per cent are based in rural settings, overall representing 20 per cent of all rural premises (Ofcom 20I3). Even when broadband access has been made available in rural areas, users are typically offered lower speeds at higher costs (Ofcom 2013). This is because geographical barriers such as mountainous regions, as well as sparse populations means that it is less commercially viable for Internet service providers to offer broadband to rural communities (Townsend et al. 2013). The pattern is similar in regards to mobile coverage, particularly in terms of $3 \mathrm{G}$ signals allowing access to broadband applications (Ofcom 20I3). The regions in the UK with the poorest access to broadband are in Wales, Scotland - particularly the Highlands and Islands and Clackmannanshire - and the North of England, particularly the North-West (Ofcom 20I2). A more in-depth discussion of the broadband infrastructure landscape in the UK, and how this impacts on rural communities and businesses, can be found in Townsend et al. 2013 .

The literature review presented above demonstrates that there is literature that highlights the value of social capital for rural businesses and points to the advantages of online networking. Yet little has been said about the relationship of online networking to social capital in business or rural contexts. This article aims to address these gaps by considering how online networking and face-to-face networking might play different roles in the development of bridging and bonding social capital for rural businesses.

(C) 2014 The Authors. Sociologia Ruralis published by John Wiley \& Sons Ltd on behalf of European Society for Rural Sociology.

Sociologia Ruralis, Vol 56, Number 1, January 2016 


\section{Methodology}

The research reported here forms part of a project that explored the potential of digital technologies for rural business networking. This study consisted of in-depth qualitative interviews with a group of I8 micro-enterprise owners based in rural areas across Scotland. The purpose of the interviews was to investigate the value of networking to the businesses, both in terms of their current networking practices and their networking-related needs, and to explore networking in online and face-to-face contexts. The sample consisted of II male and seven female owner managers of small micro-enterprises. Many of the respondents worked from home and employed few employees or were sole traders. The micro-enterprises were located in a range of rural environments in terms of population size and sparseness, and distance to urban centres, although all were in 'accessible rural' regions (Scottish Government 20I2). Even though respondents were questioned about problems relating to poor broadband speeds, none felt that this impacted on them particularly; something that contrasts starkly with work we have carried out in remoter and more sparsely populated areas of Scotland (Townsend et al. 2013). Business sectors were a mix of agriculture, food and drink, agritourism, recreational industries, property and business development. Rural businesses may serve local markets but they may also serve wider, largely urban markets and not contribute to their local community (Bosworth 20I2). In this research the rural businesses were geographically rural and contributed locally either through serving (to some extent) a rural client base or selling rural products or services. The project was carried out in partnership with a business development organisation. This organisation facilitated introductions to respondents, all of whom had participated in their rural business development course.

The study was submitted for ethical review and all respondents signed a consent form and were informed that their participation was voluntary and that they were free to withdraw at any time. Interviews mostly took place in the home or workplace of the respondents although some occurred in mutual meeting places such as coffee shops. Interview data were transcribed and uploaded to NVivo. NVivo was employed as an organisational tool, and the data were analysed independently by three researchers using framework analysis. Framework analysis allows policy-related analysis to be carried out, working with several researchers and different research fields (Spencer and Ritchie I994). The three researchers agreed on a coding frame after a preliminary analysis of the data and further interviews were coded within this framework, nevertheless allowing for the incorporation of emergent themes.

\section{Findings and discussion}

The interviews in our study reveal how differently bonding and bridging social capital is developed and valued by rural micro-enterprise owners in Scotland. The analysis pays particular attention to bonding and bridging social capital and considers the roles of face-to-face and online networking and the different ways in which the participants develop these forms of social capital, particularly in terms of differences relating to the development of trust. We also discuss findings that highlight barriers faced by some rural business owners in respect to digital skills and the adoption of ITC. 


\section{Online networking and social capital}

The use of online networking among the micro-enterprise owners relates to a number of key features characteristic of rural enterprise (namely their remoteness, lifestyle approaches and barriers to digital engagement relating to their skills levels). Remoteness can be problematic for businesses trying to work effectively as part of a wider professional community, and the development of social capital has potential in addressing its challenges. Respondents described how they use technology in order to develop and maintain social capital. For example, for those in remote locations, using online tools such as Twitter to build networks can lead to larger numbers of connections than would have been possible using face-to-face networking, thereby reducing the barrier of distance and enhancing bridging social capital:

We do a search of delis or farm shops on Twitter and follow them and they generally will have a look at your profile and either follow you back ... the price of fuel ... even if we weren't based up in this part of Scotland, the cost of fuel to get round all these guys and get to know who they are would just be extortionate. (Interview 5).

Such activity demonstrates an intention to develop bridging social capital through the use of online tools where physical distance renders face-to-face networking less practical. Indeed, for those of our respondents based in locations unlikely to experience many people passing through, networking online meant reaching more people than relying on passers-by:

Yes, the location - if I was relying on that as my sole means of marketing or advertising then it definitely would be an issue because you would then need to actively sell it. You'd want people to see you and they've not driven past for months and knew somebody new had taken over. (Interview I5)

Many of the micro-enterprise owners value lifestyle over growth, running their businesses in a way that is consistent with values such as family commitments and social life. Online communication and networking allows a more flexible approach: 'if I need to get in touch with somebody I can do that at midnight by e-mail or whatever, so it gives you a certain flexibility' (Interview 4):

purely through the practicalities the way that my life is, e-mails work very well because if I'm up a mountain all day I can't be taking a phone call and I just have to reply to e-mails (Interview I6)

and;

you just send the e-mail and you get a response at some point ... normally what you are doing or what I'm doing doesn't need an instant response so if I'm looking for information or to arrange a date then you fire off the e-mail. And because I'm based at home then I can keep check on it. (Interview Io).

Online networking therefore allows rural business owners to successfully network and develop social capital working from a rural location and without compromising values such as those relating to family life.

(C) 2014 The Authors. Sociologia Ruralis published by John Wiley \& Sons Ltd on behalf of European Society for Rural Sociology.

Sociologia Ruralis, Vol 56, Number 1, January 2016 
As stated elsewhere in this analysis, online networking can contribute to strengthening bonding capital only once a face-to-face relationship has been established. Our findings suggest that online networking is most useful in building bridging social capital - an observation in line with others who have argued that online networking is most useful in bridging processes (Ellison et al. 20II; Hampton et al. 20II). Respondents were using a variety of digital approaches to developing bridging social capital, such as e-mail:

Every time somebody contacted us, if they'd CC'd it to three other people, we just add them to our database because they've got the unsubscribe option ... I send the newsletter out, three stories in it every quarter. (Interview I5)

An online presence often bridges the micro-enterprises to new contacts and networks: 'I have sold a couple of first aid courses, people have just found us online and they've been down in Milton Keynes or somewhere. Brilliant - that's great' (Interview I6). In particular, Facebook and Twitter were seen as powerful tools for bridging to new networks, particularly through the sharing, liking and re-tweeting functionalities: 'I put out a tweet yesterday about organic milk ... and my 380 followers followed it and there was a PR food journalist who re-tweeted that to 8,000 people' (Interview I4). Once these bridges are built, the new 'followers' have the potential to engage further with organisations using online tools: 'they follow us on Facebook or they follow us on Twitter ... they know us, they like us, they love us - they are a shorter step to becoming customers' (Interview 5) and

when we need knowledge about a product I've got no idea about then I've got the ability to pull that knowledge in [from online networks]. Without cost, without taking on a consultant - not paying for a consultant to go and investigate for us. (Interview 8)

This demonstrates the potential benefits of bridging capital developed online, particularly in social media environments. Bridging to new people was also perceived as beneficial in terms of marketing and public relations:

The journalists are very avid supporters of Twitter, they use it a lot and often they get story ideas from it ... often you'll find that journalists will come up and say 'I'm really interested in following this up as a feature, can I talk to you about it?’ (Interview 9).

We generally found that Twitter was perceived as more useful for networking with other businesses, whereas Facebook was seen to be more useful in connecting with potential customers. Generally speaking our respondents had mostly tried LinkedIn but did not really understand its value, seeing it largely as a list of potential contacts with limited opportunities for interactions.

Not all respondents were embracing online tools for networking purposes. It is well documented that digital adoption can be low in rural areas, and this was reflected by some of the respondents, who discussed various barriers to engagement, supporting authors such as Hansson et al. (2007) and Smallbone et al. (2002). A lack of relevant experience with social media tools holds some back from realising the benefits of technology. Some realise its potential value, but feel they do not have the skills or knowledge to engage effectively, for example: 
How the business is communicating, we are attempting to broaden the spectrum and use social networking to our advantage but it's quite scary. We don't really know what we're doing, we've got lots of ideas but it's got to feel right for me and for the business. (Interview I3)

Others were familiar with social media, particularly Facebook, as a social tool, but could not associate it with a business or professional context: 'Facebook because I use that for personal [sic] and people might know my name. I don't really want a whole “liking” [sic]' (Interview I5). Yet the same respondent decided to embrace Twitter on learning that a large number of his clients used it: 'I didn't feel Twitter was something we could do ... [but then] actually found 60, 70 per cent of all our customers Tweet so I follow them and Tweet' (Interview I5). This shows a business owner attempting to strengthen social capital among a group of clients, perhaps with the hope of further business or contacts.

As mentioned previously, our respondents had all participated in a business development course which had been run by a business development agency. ${ }^{2}$ The course had helped one of the micro-business owners to understand the value of embracing online communications in order to expand their networks, particularly in terms of social media:

[C]ertainly if anything, through doing the [course] thing I'm more switched on perhaps now to strengthen [online networking] and say my LinkedIn contact book has ballooned from what it was so we are pushing that a bit harder. (Interview I8)

However, another respondent shows frustration that the same ethos is not held by the other participants on the course, with whom he would like to actively network beyond the completion of the course: 'this is the problem with the Rural Leadership - not everybody is on LinkedIn, not everybody is on Twitter and not everybody is comfortable with e-mail' (Interview I5). So, although the course had helped some to understand the value of online networking, not all participants had embraced this advice, limiting the potential value of online networking within this particular group.

The business sector that respondents belong to might relate to their levels of digital literacy. Overall, the farmers indicated lower digital literacy and adoption of technologies than those in sectors such as agritourism, food and drink and business services:

Out of my 28 farmers, I've got e-mail addresses for about 25. So there's three that don't have a computer ... There's another five that don't know how to use a computer ... they'll give me their wives' e-mail address, their daughter's e-mail address. (Interview I4)

Farmers tend to spend more time outside, typically needing to communicate mostly with nearby farmers:

Nobody is sitting at their computer all day. The easiest way to get them is to drive over and see which field the landrover is in and go and speak to them! (Interview 6)

This finding suggests that different sectors in rural areas might use technologies differently in the development of social capital - for example, perhaps some farmers place more value on bonding social capital and prefer to maintain such relationships through face-to-face interactions. Yet there seemed to be a growing realisation that 
e-mail communication is necessary, and some respondents have developed strategies to online communication which account for their particular skills:

More and more of the e-mails I do are now in my phone and I can now type faster on a phone than I can on a keyboard because it's just two thumbs. (Interview 7)

Mobile communications may be more appropriate for those rural business owners whose main work is based outdoors or away from the home.

For those who are more digitally literate and keen to use online business tools, this can be impeded by the skill levels of those they are collaborating with:

I have tried some of the linked tools where you have a scribble pad and you are able to show presentations and they do work well but again it's having people that know how to use it otherwise you spend half an hour explaining to them how to download the tool that they need. (Interview 9)

This reminds us that online networking relies on many members in a region or professional network to engage. The benefits of technology in the development of rural social capital may be limited by the varying skills or actors in rural regions. This is something that is recognised by some of our respondents, who encouraged their peers to engage with online networking for mutual benefit, for example, 'I push people towards electronic media wherever possible' (Interview I) and

I've done some assistance with them, helping them with their social media strategies and stuff. Not so much strategies, just getting them going - just getting them on it. A lot of people talk about 'what is your strategy?' but some people just need a hand to get started. (Interview 5)

These business owners understood that online networks are more powerful when a larger number of relevant actors contribute, perhaps supporting that rural business owners are aware of the value of networks with fewer structural holes.

Trust and the role of face-to-face networking

Our data suggest that the development of bonding social capital is dependent upon face-to-face settings, although in some cases it can be further developed in online settings. This is partly because bonding social capital is often most evident at the local level, either within families or close-knit, place-based communities, and it relies on the development of trust. Bonding social capital can be inherent in rural communities, so perhaps for some respondents it is the maintenance of these existing bonds that matters: 'I suppose a lot of the businesses that we deal with ... have been in the area for certainly decades if not generations, so [we have had] long-term relationships' (Interview 6). Some of these connections are more than a generation old. For example, one farmer described a weekly lunch meeting with neighbouring farmers, which is important in maintaining and strengthening historical bonds:

[T]his is just a group of farmers ... How did we start? I think some of our fathers maybe did it ... there's maybe 40 or 50 years of history to it.(Interview I2) 
In rural communities strong ties such as these, particularly in the case of farmers, are vital to the sustainability of businesses, because historically cooperation (and sometimes collaboration) between businesses and individuals has enabled traditional forms of working to continue and new forms of working to develop. For example in the case of diversification into organic farming, neighbouring farmers must honour spraying distances in order to not contaminate organic crops, requiring some degree of cooperation between neighbours. Our data suggest that bonding social capital which in rural settings is often an outcome of connections going back may generations - might be easily developed by native rural business owners but more difficult to foster for those business owners who are new to the area; in-migrant respondents simply did not describe strong ties in the local area. This could be explained by social closure within strongly bonded networks. Yet we acknowledge that social closure may also operate against existing members of a network, where such members violate the trust or social norms of the group.

Granovetter (I973) suggests that strong ties can insulate people from the wider opportunities presented by weak ties. Yet our interview data strongly suggest that people can also value strong ties because they offer bridging opportunities. This can be seen in the case of the farmer, quoted earlier, who nurtured strong ties through weekly lunches. Here he explains that the value of strong ties is largely in enabling access to other networks:

You have your central core of seven or eight ... and then it's the connections that these guys have - the people they talk to ... That's where the customer base comes from. (Interview I2)

This is further supported by another respondent, who explained:

I did a first aid course for the hairdressers that my mum goes to. That's a direct family connection ... I guess when you start out, unless you've got a huge marketing budget it's the only way to go. You've got to just use your contacts and your networking and move that on.

and another respondent who stated that a large part of her client base was established through: 'friends, family, friends of friends, word of mouth' (Interview II).

The respondents also highlighted problems in working with stronger ties:

Some family members still use other people and wouldn't think to use me ... they are every bit as hard work as people that you've never met in your life before. (Interview I2)

and:

I wouldn't say any of them have been close friends, I think sometimes that can be bad ... if something goes wrong it gets a bit rotten and you can ruin the relationship and that doesn't work out. (Interview 7)

Although these quotations somewhat contradict what we have described elsewhere in terms of the social aspect of business networks, they provide further weight to a suggestion that, in some situations, strong ties may be more valued in the bridging rather than the bonding processes.

Face-to-face contact is not important just for existing relationships; it helps to build the trust required in new business relationships, too. In our research many of the 
respondents stressed the importance of trust in relation to developing relatively new relationships that might result in a business transaction or collaboration. Echoing Resnick (2005) and Galloway and Mochrie (2005), there was a strong consensus that online platforms were not helpful in building trusting relationships, unless online interactions were complemented by face-to-face meetings: 'A relationship can't be built on a virtual platform, I don't think' (Interview 9):

You would have to feel that you could trust somebody. And that's unlikely to be built on an e-mail ... At the very least I would want to speak to somebody on the telephone if not face-to-face. (Interview 6)

Knowing the person, trusting the person and I think you only really get that through seeing them face to face ... It helps with the trust and it helps both parties getting to know each other and you need to know each other if you are going to do business together' (Interview I8).

And you are 'blind on the Internet or even on the phone - you don't really know the person. You've got to hit it off to be able to work with them' (Interview 3).

Face-to-face meetings can help business owners gain insights into potential partners and collaborators, particularly if the meeting takes place in the other's place of business: 'I would always tend to go to them rather than them come to me because it gives me a feel of what they are doing' (Interview I7). It can also help to resolve conflicts that might not be appropriately dealt with by e-mail or phone:

[T] here's one farmer that I've got a real issue with just now, a real problem ... what I will physically do is get in the car and go and see him. And that's how I'll solve the problems. (Interview I4).

Yet respondents were also aware of the pitfalls of meeting face-to-face, for example, in relation to the efficient use of time:

[A]ctually sometimes when you are dealing by e-mail and dealing by phone you can actually be more thorough and more detailed and more effective than if you meet face-to-face, because face-to-face you chat and you never seem to [focus]. It doesn't mean that you shouldn't do it because it is really important face-to-face but sometimes you can be more effective with the non-physical. (Interview 9)

Online networking sometimes served as a space for beginning a conversation with a potential new contact, and was likewise used to continue a relationship which had been established through face-to-face interaction. This reflects the roles of online networking in terms of both bonding and bridging social capital and its benefits in terms of issues of remoteness and physical distance: 'obviously there's a relationship there ... it makes it easy to then arrange things by e-mail or phone.... Once the relationship is there you don't necessarily have to travel' (Interview 4). Here we are reminded of the importance of face-to-face communication in building trust and developing bonding social capital. We must not overstate the value of online interactions; particularly in the development of bonding capital they are most useful precisely when complementing face-to-face networking. Yet our findings strongly suggest that technologies are helpful in supporting face-to-face networking, particularly when business owners are faced with problems of geographical remoteness. 


\section{Conclusions}

Our findings suggest that micro-enterprise owners actively strive to develop social capital through networking. This contradicts those who have argued that rural businesses are not networking adequately (Burgess 2008) or have no desire to expand their networks (Curran and Blackburn I994). Indeed, the business owners understood the limitations of their rural situations and some engaged in networking (often online) in part to compensate for these limitations. All our respondents were located in accessible rural areas. We therefore note that these findings, although applicable to our sample (micro-businesses working in an accessible rural setting), might not be easily generalised to all rural businesses, for example, those working in more remote locations (such as the Highlands and Islands of Scotland, the only Scottish region not represented by our sample).

Although the business owners have strong ties and develop bonding social capital to maintain and strengthen these ties, the focus for many respondents was on bridging to new networks and opportunities. This challenges the view in the literature that rural enterprises emphasise bonding capital (Gilbert et al. 2008; Ring et al. 2010). It makes sense for rural businesses to seek bridging social capital given their physical remoteness and limited local markets and supply chains. We find that an exception here is farmers, who seem to place the most value on face-to-face interactions and are not so concerned with building new connections beyond their existing local ties. Our results indicate that bonding and bridging ties tend to overlap in rural communities - in line with Anderson and Jack (2002), bonding and bridging are not two distinct forms of social capital with different strengths and functions, but are rather best seen as two different stages along a continuum.

We found differing views on the use of online networking. Some individuals used social media as a powerful tool to drive the development of social and economic activity. Others made negative assumptions about social media or were reluctant to use the technologies available because of concerns about the time, commitment and skills required. Although online networking is useful in bridging individuals to new contacts, our findings suggest that for rural business owners, face-to-face interactions are necessary in order to build the trust required to realise the benefits of the new connections and to develop bonding capital from these. Some of the business owners were using online tools to strengthen existing ties, although the role of online networking (particularly Facebook and Twitter) was more evident in bridging to new connections (Ellison et al. 20II; Hampton et al. 20II). These findings urge caution against overstating the benefits of online social networking. In the context of rural business owners, online networking should be considered as most beneficial when it is used together with face-to-face approaches. In contrast with the fears of authors who have warned that social networking online decreases face-to-face communications (for example, Kraut et al. I998). Our study suggests that online networking can actually support face-to-face networking practices (Kujath 20II).

A final finding was that some rural business owners have less skills or confidence with digital tools and are less likely than others to adopt digital technologies in their business practices. This seems to be explained to some extent by the business sector 
they are engaged in, but here we are cautious to highlight our relatively small sample size, which is based entirely in rural Scotland.

As noted earlier in the article, there has been little research into the use of online communications by rural businesses to enhance social capital. This article makes a valuable contribution by considering the different ways that social capital is developed in face-to-face and online contexts. We have shown the important role of online engagement in the development of social capital for rural businesses and highlighted the barriers to digital adoption in rural settings. Our findings suggest that those micro-enterprises that are embracing online applications to expand their networks and activities are examples of a rise in Castell's (I996) network society. These business owners are aware of the limitations of their rural situations and are exploiting the digital tools available to them in order to more actively participate in networks beyond the local - in some cases our respondents were participating in global networks. Our findings therefore show that globalisation and the promises of time-space compression (Agnew 200I) are relevant not only to urban centres but also to rural regions and economies. Indeed, these notions may be more relevant to those working in rural regions, given their greater geographical remoteness from urban centres, potentially necessitating connections across larger distances. Here again, though, we acknowledge that those in more remote and sparsely populated regions may not benefit so greatly from the network society. Our work suggests that scholars engaging with notions of globalisation could take into account a greater range of geographical settings in their work; rurality has much to gain from these processes and therefore warrants more in-depth academic attention. Further, we suggest that in future work, rural scholars could pay more attention to digital developments and applications and to how these might advance rural economic and social development. We conclude by proposing that those rural development agencies seeking to support rural business owners might give more consideration to the value of tailored ICT training and support.

\section{Notes}

* Corresponding authors.

I The evolution of the World Wide Web from being used mostly to view static web pages, to increasingly being used to communicate with others and co-produce content online.

2 We have not named the agency in order to protect its anonymity.

\section{Acknowledgements}

The research reported here is supported by the award made by the RCUK Digital Economy programme to the dot.rural Digital Economy Hub [(EP/Go6605I/I).

\section{References}

Adler, P.S. and S.W. Kwon (2002) Social capital: prospects for a new concept. Academy of Management Review 27 (I) pp. I7-40

Agnew, J. (200I) The new global economy: time-space compression, geopolitics, and global uneven development. Journal of World-Systems Research 7 (2) pp. I33-I54 
Anderson, A.R. and S.L. Jack (2002) The articulation of social capital: a glue or a lubricant? Entrepreneurship and Regional Development I4 (3) pp. I93-210

Ashcroft, B., S. Dunlop and J.H. Love (I995) Managerial collaboration and the innovation process (Glasgow: Fraser of Allander Institute, University of Strathclyde)

Atterton, J. (2007) The 'strength of weak ties': social networking by business owners in the Highlands and Islands of Scotland. Sociologia Ruralis 47 (3) pp. 228-245

Bosworth, G. (2009) Entrepreneurial in-migrants and economic development in rural England. PhD thesis, Centre for Rural Economy, Newcastle University

Bosworth, G. (2012) Characterising rural businesses: tales from the paperman. Journal of Rural Studies 28 (4) pp. 499-506

Bosworth, G. and J. Willett (20II) Embeddedness or escapism? Rural perceptions and economic development in Cornwall and Northumberland. Sociologia Ruralis 5I (2) pp. I95-2I4

Bourdieu, P. (I984) Social space and the genesis of groups. Theory and Society I4 pp. 723-744

Bryson, J., P. Wood and D. Keeble (I993) Business networks, small firm flexibility and regional development in UK business services. Entrepreneurship and Regional Development 5 pp. 265-277

Buhalis, D. and H. Main (I998) Information technology in small and medium hospitality enterprises: strategic analysis and critical factors. International Journal of Contemporary Hospitality Management Io (5) pp. I98-202

Burgess, S.J. (2008) England's rural areas: steps to release their economic potential. Advice from the Rural Advocate to the Prime Minister. CRC67. (Cheltenham: Commission for Rural Communities)

Burnett, R. and D. Marshall (2003) Web theory: an introduction (New York: Routledge)

Burt, R.S. (I992) Structural holes (Cambridge, MA: Harvard University Press)

Castells, M. (I996) The rise of the network society, the information age: economy, society and culture. Vol I (Oxford: Blackwell)

Castells, M. (20II) A network theory of power. International Journal of Communication 5 pp. $773-787$

Chell, E. and S. Baines (2000) Networking, entrepreneurship and microbusiness behaviour. Entrepreneurship and Regional Development I2 pp. I95-2I5

Coleman, J.S. (I988) Social capital in the creation of human capital. American Journal of Sociology 94 pp. 95-9I

Curran, J. and R.A. Blackburn (I994) Small firms and local economic networks: the death of the local economy? (London: Paul Chapman)

Curran, J., R. Rutherfoord and S. Lloyd-Smith (2000) Is there a local business community? Local Economy I5 (2) pp. I28-I43

Deakins, D., R. Mochrie and L. Galloway (2004) Rural business use of information and communications technologies (ICTs): a study of the relative impact of collective activity in rural Scotland. Strategic Change I3 (3) pp. I39-I50

Department for Culture, Media and Sport (20II) Programme delivery model. Report. Available online at http://www.culture.gov.uk/images/publications/BDUK-Programme-DeliveryModel-vsi-or.pdf Accessed 3 October 20I4

Dinis, A. (2006) Marketing and innovation: useful tools for competitiveness in rural and peripheral areas. European Planning Studies I4 pp. I-9

Ellison, N.B., C. Steinfield and C. Lampe (2OII) Connection strategies: social capital implications of Facebook-enabled communication practices. New Media Q Society I3 (6) pp. $873-892$

Galloway, L. and R. Mochrie (2005) The use of ICT in rural firms: a policy-orientated literature review. Info 7 (3) pp. 33-36

Galloway, L., R. Mochrie and D. Deakins (2004) ICT-enabled collectivity as a positive rural business strategy. International Journal of Entrepreneurial Behaviour and Research Io (4) pp. $247-259$ 
Gibson, C. (2002) Rural transformation and cultural industries: popular music on the New South Wales far north coast. Australian Geographical Studies 40 (3) pp. 337-356

Giddens, A. (I99I) Modernity and self-identity (Cambridge: Polity Press)

Gil de Zuniga, H., N. Jung and S. Valenzuela (20I2) Social media use for news and individuals' social capital, civic engagement and political participation. Journal of Computer-Mediated Communication I7 pp. 3I9-336

Gilbert, E., K. Karahalios and C. Sandvig (2008) The network in the garden: an empirical analysis of social media in rural life. Proceedings of the 26 th annual conference on Human Factors in Computing Systems, Florence, Italy

Granovetter, M.S. (I973) The strength of weak ties. American Journal of Sociology 78 (6) pp. $1360-1380$

Halpern, D. (2005) Social capital (Cambridge: Polity Press)

Hampton, K.N., L.S. Goulet, L. Rainie et al. (20II) Social networking sites and our lives. Pew Research Center's Internet a American Life Project (Washington, DC)

Hansson, H., P. Mihailidis, K. Larsson et al. (2007) The Rural Wings project: bridging the digital divide with satellite-provided Internet. Phase I: identifying and analysing the learning needs of 3I communities in Io countries. E-Learning 4 (2) pp. IO7II5

Kaplan, S. and M. Sawheny (2000) E-hubs: the new B2B marketplaces. Harvard Business Review 74 (3) pp. 97-I03

Knack, S. and P. Keefer (I997) Does social capital have an economic payoff? A cross country investigation. Quarterly Journal of Economics II2 pp. I25I-I288

Kraut, R., M. Patterson, V. Lundmark et al. (I998) Internet paradox: a social technology that reduces social involvement and psychological well-being? American Psychologist 53 (9) pp. IOI7-IO3I

Kujath, C.L. (2OII) Facebook and MySpace: complement or substitute for face-to-face interaction? Cyberpsychology, Behavior, and Social Networking I4 (I-2) pp. 75-78

Leatherman, J.C. (2000) Internet-based commerce: implications for rural communities. Reviews of Economic Development Literature and Practice, 5. (US Economic Development Administration, Washington)

Lechner, C. and M. Dowling (2003) Firm networks: external relationships as sources for the growth and competitiveness of entrepreneurial firms. Entrepreneurship and Regional Development I5 pp. I-26

Lee, J., A. Árnason, A. Nightingale et al. (2005) Networking: social capital and identities in European rural development. Sociologia Ruralis 45 (4) pp. 269-283

Lin, N. (200I) Building a network theory of social capital in Social Capital. Pp. 3-29 in N. Lin, K. Cook and R.S. Burt eds, Theory and research (New York: Walter de Gruyter)

McGranahan, D.A., T.R. Wojan and D.M. Lambert (20II) The rural growth trifecta: outdoor amenities, creative class and entrepreneurial context. Journal of Economic Geography II (3) pp. 529-557

McLuhan, M. (1962) The Guttenberg galaxy (Toronto: University of Toronto Press)

Monsted, M. (I995) Processes and structures of networks: reflections on methodology. Entrepreneurship and Regional Development 7 pp. 193-213

Moyes, D., G. Whittam and P. Ferri (20I2) A conceptualisation of the relationship capital of rural small service firms. Local Economy 27 (2) pp. I36-I5I

Ofcom (20I2) Communications market report: UK. Available online at http://stakeholders .ofcom.org.uk/market-data-research/market-data/communications-market-reports/cmrı2/ Accessed 3 October 20I4

Ofcom (20I3) The availability of communications services in the UK. Available online at http://stakeholders.ofcom.org.uk/market-data-research/market-data/economic-geography Accessed 3 October 20I4 
Petrou, A., E. Fiallo-Pantziou, E. Dimara et al. (2007) Resources and activities complementarities: the role of business networks in the provision of integrated rural tourism. Tourism Geographies 9 (4) pp. 42I-440

Phillipson, J., M. Gorton and L. Laschewski (2006) Local business co-operation and the dilemmas of collective action: rural micro-business networks in the north of England. Sociologia Ruralis 46 (I) pp. 40-60

Pichler, F. and C. Wallace (2007) Patterns of formal and informal social capital in Europe. European Sociological Review 23 (4) pp. 423-435

Pichler, F. and C. Wallace (2009) What are the reasons for differences in job satisfaction across Europe?: individual, compositional and institutional explanations. European Sociological Review 25 (5) pp. 535-549

Pittaway, L., M. Robertson, K. Munir et al. (2004) Networking and innovation: a systematic review of the evidence. International Journal of Management Reviews 3/4 pp. I37-I68

Portes, A. (1998) Social capital: its origins and applications in modern sociology. Annual Review of Sociology 22 pp. I-24

Putnam, R.D. (I993) Making democracy work (Princeton, NJ: Princeton University Press)

Putnam, R.D. (2000) Bowling alone. The collapse and revival of American community (New York: Simon and Schuster)

Resnick, P. (2005) Impersonal sociotechnical capital, ICTs, and collective action among strangers. Pp. 399-4I2 in W.H. Dutton ed., Transforming enterprise: the economic and social implications of information technology (Cambridge, MA: MIT Press)

Ring, J.K., A.M. Peredo and J.J. Chrisman (20I0) Business networks and economic development in rural communities in the United States. Entrepreneurship Theory Q Practice 34 (I) pp. I7I-I95

Roper, S. (I997) Product innovation and small business growth: a comparison of the strategies of German, UK and Irish companies. Small Business Economics 9 (6) pp. 523-537

Scottish Government (20I2) Scottish government urban-rural classification 20II-2OI2 (Edinburgh: Scottish Government)

Shaw, E. (I997) The real networks of small firms. Pp. 7-I7 in D. Deakins, P. Jennings and C. Mason eds, Small firms. Entrepreneurship in the I990s (London: Paul Chapman)

Shucksmith, M. (2000) Endogenous development, social capital and social inclusion: perspectives from LEADER in the UK. Sociologia Ruralis 40 (2) pp. 208-2I8

Skerratt, S. and M. Warren (2003) Broadband in the countryside: the new digital divide. In EFITA 2003 Conference, 5-9 July 2003, Debrecen, Hungary

Smallbone, D., D. North, R. Baldock et al. (2002) Encouraging and supporting enterprises in rural areas. Report to the small business service (London)

Spencer, L. and J. Ritchie (I994) Qualitative analysis for applied policy research. Pp. I73-I94 in A. Bryman and R.G. Burgess eds, Analysing qualitative data (London and New York: Routledge)

Stern, M. (2008) How locality, frequency of communication, and Internet usage affect modes of communication within core social networks. Information, Communication and Society II (5) pp. 519-6I6

Stern, M.J. and E.A. Adams (2010) Do rural residents really use the Internet to build social capital? An empirical investigation. American Behavioral Scientist 53 pp. I389I422

Sutherland, L. and R. Burton (20II) Good farmers, good neighbours? The role of cultural capital in social capital development in a Scottish farming community. Sociologia Ruralis 5I (3) pp. $238-255$

Townsend, L., A. Sathiaseelan, G. Fairhurst et al. (2013) Enhanced broadband access as a solution to the social and economic problems of the rural digital divide. Local Economy 28 (6) pp. 580-595 
Valenzuela, S., N. Park and K.F. Kee (2009) Is there social capital in a social network site? Facebook use and college students' life satisfaction, trust, and participation. Journal of Computer-Mediated Communication I4 (4) pp. 875-90I

Wallace, C. (20I2) Can information and communications technology enhance social quality? International Journal of Social Quality 2 (2) pp. 98-II7

Warren, M. (2007) The digital vicious cycle: links between social disadvantage and social exclusion in rural areas. Telecommunications Policy 3I (6-7) pp. 374-388

Wellman, B., A. Quan Haase and J. Witte (200I) Does the Internet increase, decrease or supplement social capital? Social networks, participation and community commitment. American Behavioural Scientist 45 pp. 436-455

Leanne Townsend

King's College

University of Aberdeen

Aberdeen

UK

e-mail: I.townsend@abdn.ac.uk

Claire Wallace*

School of Social Science

King's College

University of Aberdeen

Aberdeen

UK

e-mail: claire.wallace@abdn.ac.uk

Alison Smart

The Business School

University of Glasgow

Glasgow

UK

e-mail: Alison.Smart@glasgow.ac.uk

Timothy Norman

King's College

University of Aberdeen

Aberdeen

UK

e-mail: t.j.norman@abdn.ac.uk 